\title{
Yaratıcılık ve hoşgörü: Okul öncesi öğretmen adayları üzerine bir araştırma*
}

\section{Creativity and tolerance: A research on preschool teacher candidates}

\author{
Hilal Yılmaz ${ }^{1}$, Yıldız Güven ${ }^{2}$
}

\begin{abstract}
Makale Geçmişi
Geliş : 13 Mayıs 2019

Düzeltme : 19 Haziran 2019

Kabul : 23 Haziran 2019

Çevrimiçi : 02 Temmuz 2019
\end{abstract}

Makale Türü

Arastırma Makalesi

Article History

Received : 13 May 2019

Revised : 19 June 2019

Accepted : 23 June 2019

Online : 02 July 2019

Article Type

Research Article
Öz: Bu araştırmanın amacı, okul öncesi öğretmen adaylarının yaratıcılık ve hoşgörü düzeyleri arasındaki ilişkinin incelenmesidir. Nicel araştırma yöntemlerinden ilişkisel tarama modeli kullanılmıştır. Araştırmanın çalışma grubunu, 2018-2019 eğitim ve öğretim yılında İstanbul ilinde yer alan iki devlet ve bir vakıf üniversitesinin Okul Öncesi Ë̆itimi Anabilim Dalı'nda öğrenim gören 1. ve 4. Sınıf toplam 215 okul öncesi öğretmen adayı oluşturmaktadır. Araştırmada veri toplama araçları olarak "Kişisel Bilgi Formu", "Yaratıcı Kişilik Özellikleri Ölçeği” ve "Hoşgörü Ölçeği” kullanılmıştır. Araştırmanın sonucunda, okul öncesi öğretmen adaylarının yaratıcılık ve hoşgörü düzeylerinin yüksek olduğu, yaratıcılık düzeyleri ile hoşgörü düzeyleri arasında yüksek düzeyde, pozitif ve anlamlı bir ilişki $(\mathrm{p}=.000$, $r=.77$ ) olduğu tespit edilmiştir. Öğretmen adaylarının yaratıcılık ve hoşgörü düzeyleri cinsiyet ve sınıf düzeyi değişkenlerine göre anlamlı bir farklılık göstermezken ( $\mathrm{p}>.05)$, yaratıcılık ve hoşgörü düzeyleri yaratıcılık dersi alan öğretmen adaylarının lehine anlamlı farklılık $(\mathrm{p}<.05)$ göstermektedir.

Anahtar Kelimeler: Okul öncesi öğretmen adayları; Yaratıcılık; Hoşgörü

Abstract: The aim of this study is to examine the relationship between the levels of creativity and tolerance of preschool teacher candidates. A relational survey model was used for quantitative research methods. The study group consisted of 215 preschool teacher candidates in the 1 st and 4 th classes of the preschool education departments of two state and one foundation university in Istanbul province during the 2018-2019 academic year. The study determined that preschool teacher candidates had high levels of both creativity and tolerance, and that there was a positive and significant relationship between creativity levels and tolerance levels $(\mathrm{p}=.000, \mathrm{r}=.77)$. While the levels of creativity and tolerance of teacher candidates did not show a significant difference according to gender and grade-level variables $(p>.05)$, creativity and tolerance levels showed a significant difference $(p<.05)$ in favor of teacher candidates who had taken a creativity course.

Keywords: Preschool teacher candidates; Creativity; Tolerance

${ }^{1}$ Marmara Üniversitesi, Atatürk Eğitim Fakültesi, Temel Eğitim Bölümü, Okul Öncesi Eğitimi Anabilim Dalı, hilal.vilmaz@marmara.edu.tr, ORCID: https://orcid.org/0000-0002-4594-3155

${ }^{2}$ Marmara Üniversitesi, Atatürk Eğitim Fakültesi, Temel Eğitim Bölümü, Okul Öncesi Eğitimi Anabilim Dall, vguven@marmara.edu.tr, ORCID: http://orcid.org/0000-0002-5120-7381 


\section{SUMMARY}

\section{Introduction}

According to Runco (2007), the world is undergoing a serious cultural evolution. Creativity becomes more important in the face of rapid changes. Creativity is also important for the advancement of science and technology and is critical for the development of society (Robinson, 2001). Torrance (1981) stated that creative teachers make a difference in their societies. Being sensitive to events in the outside world, being open to communication and criticism, exhibiting independent behavior, and possessing problem-solving skills are among the characteristics of creative people (Üstündağ, 2005). In addition to these features, teachers are expected to be able to evaluate the events around them from different perspectives, and be tolerant and respectful of different ideas (Sternberg and Grigorenko, 2004).

Tolerance is the acceptance of people, life, and the environment in their natural states (Aslan, 2001); it is characterized by an open-minded attitude and respect for uncertainties, individuals' ethnic, social backgrounds, and the lifestyle they choose (Florida 2003; Hotaman, 2012). In short, tolerance is one of the values that are important for children in educational institutions, so it is important for teachers to sustain the tolerance approach in educational environments (Büyükkaragöz and Kesici, 1996; Kesici, 1996; K1liç, 2006; Yetim and Göktaş, 2004; Üste, 2007).

By virtue of their training, teacher candidates are expected to acquire their characteristics for qualification in all aspects and model behavior that is suitable for their profession. It is important to offer an educational program that takes into consideration the individual needs of children, adopts modern educational approaches, are operates in awareness of the reality that every child is raised in a different culture and environment, and whose teachers are creative individuals with an understanding of tolerance (Boyac1 and Ersever, 2017; Çoban, Karaman and Doğan, 2010; Yeşilkayalı and Yıldız Demirtaş, 2013).

In the light of the literature and considering how it will contribute to the field, the main purpose of this study was determined as an investigation of the relationship between tolerance and creative personality levels of preschool teacher candidates, who are the teachers of the future. For this purpose, the tolerance and creative personality levels of teacher candidates and the differentiation of the candidates' tolerance and creativity levels according to their demographic characteristics will be examined (gender, grade level and the completion of a creativity course).

\section{Method}

This study was designed using a relational survey model. Data collection tools used in the research are: "Personal Information Form," “Tolerance Scale," and "Creative Personality Traits Scale. The study sample consisted of 215 preschool teacher candidates from the 1st and 4th grades of the preschool education 
departments of two state and one foundation universities in Istanbul province, during 2018-2019 academic year.

\section{Results}

The study determined that preschool teacher candidates had high levels of creativity and tolerance, and that there was a positive and significant relationship between creativity levels and tolerance levels $(p=.000, r=$ .77). While the levels of creativity and tolerance of teacher candidates did not show a significant difference according to gender and grade level variables $(\mathrm{p}>.05)$, creativity and tolerance levels showed a significant difference $(\mathrm{p}<.05)$ in favor of teacher candidates who had taken a creativity course.

\section{Conclusion and Discussion}

In this study, it was observed that the level of tolerance and creativity of the teacher candidates comprising the sample were high. There are many studies indicating that preschool teacher candidates have high levels of creativity (Çetingöz, 2002; Ekinci and Kaya, 2016; Görgen and Karaçelik, 2009; Temizkalp, 2010; Toyran, 2015; Zeytun, 2010). This result is a positive finding for future teachers.

A positive and significant relationship was found between tolerance and creativity levels of preschool teacher candidates. Many researchers have reported the positive relationship between individuals' tolerance levels and creativity as a result of their studies (Barron and Harrington, 1981; Kornilova and Kornilov 2010; Stoycheva, 2009; Stoycheva, 2008; Tegano, 1990; Zenasni, Besancon and Lubart, 2008). In contrast, Merrotsy (2013) examined the research conducted on this subject and stated that this relationship is not very strong and should be studied more (especially in the field of education).

It was revealed that the level of tolerance and creativity of preschool teacher candidates did not differ according to their gender variables. Some researchers also found that the level of creativity of preschool teacher candidates did not differ according to gender (İşleyen and Küçük, 2013; Temizkalp, 2010; Topoğlu, 2015; Zeytun, 2010). Büyükkaragöz and Kesici (1996) found a significant difference in tolerance among elementary-school teachers, in favor of female teachers. In the literature, there are findings that women are perceived as more tolerant than men due to their social and gender roles (Babaoğlan, 2016; Yetim, 2002).

It was revealed that the level of tolerance and creativity of preschool teacher candidates did not differ according to their grade levels. This finding overlaps with some other research findings (Topoğlu, 2015) but not others (Çetingöz, 2002; Görgen and Karaçelik, 2009; Zeytun, 2010). This result may be related to whether or not the teacher candidates developed these personal traits rather than grade level. Among the preschool teacher candidates who participated in the research, the level of tolerance and creativity of those who took the creativity course was found to be higher than those who did not take the course, which can be explained as a positive effect of the courses taken on teacher candidates. 
As a result of this research, some suggestions can be submitted to researchers and practitioners. For example, higher education institutions that train teachers can enrich their programs, particularly to increase the teacher candidates' awareness of about tolerance and creativity, and to improve them in these aspects. New studies can be conducted with different sample groups using qualitative research methods. 


\section{GİRIŞ}

Değişen dünya ile birlikte geleneksel değerler yerini güncel evrensel değerlere bıraktı. Bunlar; özgürlük, adalet, uzlaşma, barış, bilgi, yaratıcılık ve hoşgörüdür (Altunay ve Yalçınkaya, 2011). Runco'ya (2007) göre, dünya aslında ciddi bir kültürel evrim geçirmektedir. Bu nedenle hızlı değişimler karşısında yaratııılık daha da önem kazanmaktadır. Yaratıcılık bilim ve teknolojinin gelişimi için önemli olup, toplumun gelişimi için de kritik bir öneme sahiptir (Robinson, 2001). Mumford, Medeiros ve Partlow’a (2012) göre kısmen çözülmüş veya hiç çözülmemiş problemler için yaratıcllık son derece gerekli bir unsurdur ve ancak yaratıcı düşünen insanlar dünyadaki hızlı değişimlere ayak uydurabilirler. Beghetto (2007) yaratıcıllğın 21. yüzyıl için anahtar bir güç olduğunu söyler. Torrance (1981) ise yaratıcı öğretmenlerin toplumlar üzerinde fark yaratacak güçte olduğunu ifade etmiştir.

Vygotsky (2004) yaratıc1lı̆̆ eski bellekte olanların yeniden yapılandırılarak veya üzerinde çalışılarak yeni fikirlerin ve davranışların ortaya konulduğu bir süreç olarak tanımlamaktadır. Mumford (2003) yaratıcılığı; elle tutulabilen-somut (buluşlar gibi) ve elle tutulamayan-soyut (görüşler veya teoriler gibi) yeni ve değerli şeyler üretme olarak tanımlamıştır. Yaratıcılık genel yetenekler, kişisel özellikler ve problem çözme becerisi isteyen karmaşı bir insan özelliğidir. Yaratıcı bireylerin temel niteliklerine bakılacak olursa, merak duygusu gelişmiş, sabırlı, bilinmeyene ve yeni fikirlere karşı hoşgörülü, maceracı, soyut düşünebilen, hayal kurmayı seven ve araştırmacı kişiler oldukları bilinmektedir (Benedek, Nordtvedt, Jauk, Koschmieder, Pretsch, Krammer ve Neubauer, 2016; Csikszentmihalyi, 2015; Saracho, 2002; Zachopoulou, Makri ve Pollatou, 2007; Zachopoulou ve Makri, 2005; Zenasnı, Besançon ve Lubart, 2008). Bunun yanı sıra dış dünyada olan biten olaylara duyarlı olma, iletişime ve eleştiriye açık olma, bağımsız davranış sergileyebilme ve sorun çözme becerisine sahip olma yaratıcı kişilerin özellikleri arasında sayılmaktadır (Üstündağ, 2005).

21. yüzyılı yaşayan bir bireyde olması beklenen yaratıcı düşünme yeterlilikleri okul öncesi eğitim kademesinden itibaren her eğitim kademesinde pekiştirilerek bireylere kazandırılmalıdır. Daha da önemlisi bu yeterlilikleri kazandıracak öğretmenin de bu yeterliliklerle donanmış olması gerekmektedir. Bu sebeple öğretmen yetiştiren kurumlarda öğretmen adaylarının yetiştirildiği programdaki derslerin üst düzey düşünme yeterliliklerini geliştirebileceği etkinliklerle düzenlenmesi büyük bir önem arz etmektedir (Kaya, 2010).

Yaratıcılık alanyazında; yetenek, kişilik ve bilişsel boyutta ele alınmış olup, uzun yıllar araştırılmış ve araştırılmaya devam edilecek bir kavramdır. Öğretmen açısından yaratıcılığın kişilik boyutuna bakıldığında, öğretmenlerin çevrelerindeki olayları farklı açılardan değerlendirebilen, hoşgörülü ve farklı düşüncelere sayg1 gösteren bir kişilik yapısında olmaları beklenmektedir. Ancak yaratıcı 
öğretmenler sınıflarındaki çocukların yeni fikirlerini destekleyerek, bakış açılarını geliştirerek ve onları ödüllendirerek onların yaratıcı düşünmelerini sağlayabilir (Sternberg ve Grigorenko, 2004). Bunun için öğretmenlerin çocuklara güven verici, farklı düşüncelerini destekleyici bir ortam sunmaları, bireysel özelliklerini dikkate alarak değerlendirmeleri, onları her koşulda sevmeleri ve sayg1 göstermeleri önemlidir (Çelik, 2011; Erdoğdu, 2006; Tegano, Groves ve Catron, 1999; Tuncel ve Balcı, 2015; Yıldırım, Ünal ve Çelik, 2011).

Hoşgörü ise; insanları, yaşamı ve çevreyi kendi doğal halleriyle kabul etmek olup (Aslan, 2001), belirsizliklere, bireylerin etnik, sosyal geçmişlerine ve seçmiş oldukları hayat tarzına karşı açık fikirli olmak ve sayg1 göstermekle karakterize tutumlardır (Florida 2003; Hotaman, 2012). Hoşgörü, aynı zamanda farklı düşünce ve davranışları insancıl bir anlayışla karşılama, bir kısım hatalı davranışlara tahammül gösterip cezalandırmaya kalkışmama, farklılıkları kültürel bir zenginlik ve çeşitlilik olarak görme ve yaşamda onlara yer verme anlamına da gelir (Cihan, 1998; Korkmaz, 2000). Aydın (2016), hoşgörü anlayışının ilkelerini; her insanın biricik ve değerli olduğunu kabul etme, insanları tüm yönleriyle tanımaya çalışma, farklılıklara saygı gösterme, eleştiriye açık olma, empati ve iyi birer dinleyici olma olarak ifade etmiştir. Kısaca hoşgörü, karşıllklı anlayış ve yaşam şeklidir.

Hoşgörü anlayışının kazanılması ve kalıcı davranış haline getirilmesi eğitim ortamları ile sağlanmaktadır (Büyükkaragöz ve Kesici, 1996; Üste, 2007). Şüphesiz ki karşımızdaki kişilere hoşgörülü davranmak aynı zamanda çok kültürlü eğitimin de amaçları arasında yer almaktadır ve bunun öğretimi öğretmenler tarafindan gerçekleştirilmektedir (Banks, 2008; Polat, 2009; Yazıc1, 2017). Bununla birlikte eğitim ortamları açısından hoşgörü, idare-öğretmen-öğrenci-veli ve diğer personellerin birbirlerinin kusurlarına tahammül göstermeleri ya da bu kusurları görmezden gelmeleri anlamına gelmez. Hoşgörü, aynı sosyal çevreyi paylaştı̆̆ımız kişilere saygı ve sevgi sınırları içinde kusurlu olunan kısımları ifade etmek, bu kusurları kabullenmek ve yaşanan durumlar karşısında hissedilenleri karşımızdaki kişiye ifade etmek anlamını da taşır (Çınkır, 2004; Kıroğlu, Elma, Kesten ve Egüz, 2012). Kısaca hoşgörü, eğitim kurumlarında çocuklara benimsetilmesi önemli olan değerlerden bir tanesi olup, öğretmenlerin eğitim ortamlarında hoşgörü anlayışını yaşatabilmeleri önemli bir husustur (Büyükkaragöz ve Kesici, 1996; Kllıç, 2006; Yetim ve Göktaş, 2004). Nitekim, hoşgörü anlayışına sahip bir okul öncesi öğretmeni; çocukların duygularını kabul eder, onları yarg1lamaz, onlara farklı öğrenme yöntemleri sunar, çocukları takdir eder ve olumlu davranışları pekiştirir (Büyükkaragöz ve Kesici, 1996; Türe ve Ersoy, 2015).

Şüphesiz ki erken çocukluk döneminde hoşgörü sahibi olmak, çocukların başkalarıly ilişkili olarak kendilerini geliştirmeye yönelik farkındalıklarını ve birinin kendisinden farklı bir görünümde olmasını ve farklı bir davranışı kabul etme yeteneğini ifade eder (Zakin, 2012). Doğuştan getirilen 
bir özellik olmayan hoşgörü, çocukların önce ailelerinde sonra okulda öğretmen ve arkadaşlarıyla etkileşimleri sonucunda öğrendikleri bir kavramdır (Kalın ve Nalçacı, 2017).

Okul öncesi eğitim programında yer alan hedef değerlerden biri olan hoşgörü kavramının (Sapsağlam, 2016) çocuklara öğretilmesi için etkili yöntemler tespit edilmeli ve bu yöntemler erken dönemlerde uygulanmaya başlanmalıdır (Akandere, Yarımkaya ve Aslan, 2014; Aslan, 2017; Aydın, 2010). Öğretmenler uygun yöntemleri kullanarak, hoşgörü aracığıyla oluşturdukları olumlu sınıf atmosferi ve karşılıklı iletişim içerisinde etkili bir öğretim gerçekleştirebilirler (Başarır, Sarı ve Çetin, 2014; Bayraktar ve Çınar, 2010; Kıroğlu, Elma, Kesten ve Egüz, 2012).

Diğer taraftan, 21. yüzyıl çocuklarını yetiştiren öğretmenlerin üç yeterlilik alanında kendilerini geliştirmeleri ve bu becerilere sahip olmaları beklenmektedir. Bunlar kişisel yeterlikler, alan yeterliği ve eğitsel yeterliklerdir. Sorumluluk sahibi olma, yaratıcılık, problem çözme becerisi, eleştirel düşünme, iş birliğine dayalı çalışabilme becerisi, değişime açık olma, anlayış ve hoşgörü sahibi olmak kişisel yeterlikler içerisinde sayılmaktadır. Alan yeterliliği kapsamında ise; mesleki bilgiye sahip olmak yer almaktadır. Son olarak eğitsel yeterlik ise öğretme ile ilgilidir (Kılıç, Kaya, Yıldırım ve Genç, 2004; Sünbül, 2006). Öğretmenlerin kişisel yeterlikleri içerisinde yer alan yaratıcıllk ve hoşgörü kavramlarına bakılacak olursa; her iki kavram da birbirini karşılıklı yönde etkilemekte, hoşgörü sahibi bireyler yaratıcıllı̆̆1 desteklerken, yaratıcı düşünebilen bireyler de hoşgörülü olmaktadırlar (Üstündağ, 1998).

Bu bağlamda değerlendirildiğinde öğretmenlerin hoşgörülü bir tutuma sahip olmamaları çocuklar için yaratıcı düşünmenin de oluşmasına engel olmaktadır (Çelik, 2011; Rıza, 2004; Yıldız, 2018). Hem okul hem de aile yaşantısında, çocuğa esnek ve hoşgörünün hâkim olduğu bir ortamın sunulması çocuğun yaratıcıllğını geliştirmektedir (Oğuzkan, Demiral ve Tür, 2001). Nitekim yaratıcılığı açıklayan teoriler yaratıcılığın okullarda daha fazla yer almasını savunmaktadırlar (Mullen, 2018). Torrance'a göre (1972) çocukların tüm fikirlerinin hoşgörü anlayışı içerisinde değerlendirildiği, güven veren bir sınıf ortamı çocuklardaki yaratıcılı̆̆ın gelişmesini sağlar. Kendi yaşamında yaratıcı düşünme becerisine sahip, bunu önemseyen, eğitimin olmazsa olmazı olarak gören bir öğretmen ise, sınıfinda oluşturacağı ortam ile yaratıcı çocukların fikirlerini hoş görecek ve yaratıcı ürünler ortaya çıkarmaları konusunda onları desteklemiş olacaklardır (De Souza, 2000; Özerbaş, 2011).

Öğretmen adaylarının aldıkları eğitim sayesinde her yönüyle nitelikli öğretmen özelliklerini kazanmaları, mesleklerine yakışan davranış modellerini sergilemeleri beklenmektedir. Bu nitelikler içerisinde ilk sırada öğretmen adaylarının çocuklara, hangi bilgiyi, hangi yöntemlerle ve ne zaman öğretecekleri gelmektedir. Bunun yanı sıra, çocukların bireysel farklılıklanını dikkate alarak, 
demokratik bir öğrenme ortamı oluşturulması önemlidir. Çocukların bireysel ihtiyaçlarının dikkate alındığı, çağdaş eğitim yaklaşımlarının benimsendiği, her çocuğun farklı bir kültür ve çevrede büyüdüğ̈u gerçeği ile yürütülen bir eğitim programının sunulması ve bu sistem içerisindeki öğretmenlerin hoşgörü anlayışına sahip yaratıcı bireyler olmaları önemlidir (Boyacı ve Ersever, 2017; Çoban, Karaman ve Doğan, 2010; Yeşilkayalı ve Yıldız Demirtaş, 2013). Moran'ın (2010) hoşgörü kavramına ilişkin yürüttüğü çalışma, hoşgörü düzeyi yüksek bireylerin esnek düşünen ve çevrelerindeki bireyleri olduğu gibi kabul eden kişiler olduklarını ortaya koymuştur. Kısaca öğretmen adaylarının hoşgörü bilincine sahip olmaları, ileride sınıflarındaki çocukların farklı fikirleri dile getirmelerine, öğretmen-öğrenci iletişiminin daha sağlıklı olmasına katkı sağlayacaktır (Erdoğdu, 2006; Sadık, 2002).

Alanyazında yer alan çalışmalarda okul öncesi öğretmen adaylarının yaratıcılık düzeyleri (Çetingöz, 2002; Görgen ve Karaçelik, 2009); yaratıcılık ve problem çözme düzeyleri (Zeytun, 2010); öğretmenlik mesleğine yönelik tutumları ile yaratıcılık becerileri (Kesicioğlu ve Deniz, 2014); yaratıc1 düşünme düzeyleri ile eleştirel düşünme eğilimleri (Toyran, 2015) ve iletişim, yaratıcıllk ve estetik (Ekinci ve Kaya, 2016) arasındaki ilişkileri inceleyen çalısmalar mevcuttur.

Hoşgörü kavramı ise alanyazında bir değer olarak (Gülay Ogelman ve Erten Sarıkaya, 2015; Stone, 2000; Oğuz, 2012; Uzun ve Köse, 2017) ya da öğretmen niteliği olarak (Çalışkan, Negiş Işık ve Saygın, 2013; Çekin, 2013; Polat, 2009) ele alınmıştır. Öğretmenlerle yaratıcılık ile hoşgörü ilişkisi (Kornilova ve Kornilov, 2010) üzerine bir çalışma yürütülmüştür fakat okul öncesi öğretmen adaylarının hoşgörü düzeylerinin incelendiği herhangi bir çalışmaya rastlanmamıştır. Mesleğe başlamadan önce genç öğretmen adaylarının yaratıcılık ve hoşgörü düzeylerinin incelenmesi, ileride onlara sunulacak programın ve eğitimin içeriğinin şekillenmesi açısından önemlidir. Öğretmen olmadan önce onlara kazandırılacak yaratıcılık ve hoşgörü gibi kişisel değerler erken dönemde öğretmen niteliğini artırmada önemli görülmektedir.

Alanyazındaki çalışmalar 1şı̆̆ında alana katkı sağlayacağı da düşünülerek, geleceğin öğretmenleri olan okul öncesi öğretmen adaylarının yaratıcllık ve hoşgörü düzeyleri arasındaki ilişkinin incelenmesi çalışmanın temel amacı olarak belirlenmiştir. Bu temel amaçla birlikte, öğretmen adaylarının yaratıcılık ve hoşgörü düzeyleri belirlenerek, yaratıcılık ve hoşgörü düzeylerinin demografik özelliklerine (cinsiyet, sınıf düzeyi ve yaratıcılık dersi alıp almama durumu) göre farklılaşma durumları incelenmiştir. 


\section{YÖNTEM}

\section{Araştırma Modeli}

Bu çalışmada, okul öncesi öğretmen adaylarının yaratıcllık ve hoşgörü düzeyleri arasındaki ilişkiyi incelemek amacıyla ilişkisel tarama modeli kullanılmıştır. Tarama modelleri geçmişte ya da halen var olan bir durumu var olduğu şekliyle betimlemeyi amaçlayan araştırma yaklaşımlarıdır. Araştırmaya konu olan olay, birey ya da nesne, kendi koşulları içinde ve olduğu gibi tanımlanmaya çalışılır. Onları herhangi bir şekilde değiştirme, etkileme çabası gösterilmez. Önemli olan bir durumu uygun bir biçimde "gözleyip" belirleyebilmektir (Karasar, 2005).

\section{Çalışma Grubu}

Araştırmanın çalışma grubunu, 2018-2019 eğitim ve öğretim yllında İstanbul ilinde yer alan iki devlet ve bir vakıf üniversitesinin Okul Öncesi Eğitimi Anabilim Dalı'nda öğrenim gören, çalışmaya gönüllülük ilkesi doğrultusunda katılan 1. ve 4. Sınıf toplam 215 okul öncesi öğretmen aday1 oluşturmaktadır. Çalışmanın yürütüldüğü üniversitelerde yaratıcılık dersinin 2. ve 3. Sınıf öğretim programında yer alması nedeniyle çalışma grubu, normal öğretim sürecinde yaratıcılık dersini henüz almayan 1. Sınıflar ve yaratıcılık dersini almış olan 4. Sınıf öğretmen adaylarından oluşmaktadır.

Araştırmanın çalışma grubuna ait demografik bilgilere Tablo 1'de yer verilmiştir.

Tablo 1. Öğretmen adaylarına ait demografik bilgiler

\begin{tabular}{llll}
\hline Demografik Bilgiler & & $\mathrm{N}$ & $\%$ \\
\hline \multirow{2}{*}{ Cinsiyet } & Kadın & 204 & 94.9 \\
& Erkek & 11 & 5.1 \\
\hline \multirow{2}{*}{ Üniversite } & Devlet & 140 & 65.1 \\
& Vakıf & 75 & 34.9 \\
\hline \multirow{2}{*}{ Sinıf düzeyi } & 1. Sınıf & 104 & 48.4 \\
& 4. Sinıf & 111 & 51.6 \\
\hline \multirow{3}{*}{ Mezun olunan lise türü } & Fen Lisesi & 2 & .9 \\
& Anadolu Öğretmen Lisesi & 37 & 17.2 \\
& Anadolu Lisesi & 64 & 29.8 \\
& Imam Hatip Lisesi & 22 & 10.2 \\
\multirow{2}{*}{ Yaratıcllık dersi alma durumu } & Düz Lise & 37 & 17.2 \\
& Meslek Lisesi & 53 & 24.7 \\
\hline \multirow{2}{*}{ Toplam } & Alan & 91 & 42.3 \\
& Almayan & 124 & 57.7 \\
\hline
\end{tabular}

\section{Veri Toplama Araçları}

Araştırmada veri toplama araçları olarak okul öncesi öğretmen adaylarının demografik bilgilerine ulaşmak amacıyla; “Kişisel Bilgi Formu”, öğretmen adaylarının yaratıcılık düzeylerini belirlemek 
amacıyla "Yaratıcı Kişilik Özellikleri Ölçeği”" ve hoşgörü düzeylerini belirlemek amacıyla "Hoşgörü Ölçeğì" kullanılmıştır.

\section{Kişisel bilgi formu}

Araştırmacılar tarafından geliştirilen Kişisel Bilgi Formu'nda, öğretmen adaylarının demografik özelliklerini (cinsiyet, sınıf düzeyi ve yaratıclık dersi alıp almama durumu) belirlemeye yönelik sorular yer almaktadir.

\section{Yaratıcı Kişilik Özellikleri Ölçeği}

Yaratıcı Kişilik Özellikleri Ölçeği, Şahin ve Danışman (2017) tarafından öğrencilerin yaratıcı kişilik özelliklerinin değerlendirilmesi amacıyla geliştirilmiştir. Ölçek amaç yönelimlilik, içsel motivasyon, kendine güven ve risk alma olmak üzere dört alt boyut ve toplamda 17 maddeden oluşmaktadır. Beşli Likert tipinde olan ölçeğin alt boyutlarına ait Cronbach Alpha kat sayısı değerleri sırasıyla .65, .60, .64 ve .64 olarak belirlenmiştir. Ölçeğin toplam Cronbach Alpha kat sayısı .67'dir. Ölçek toplam puan üzerinden değerlendirilmiştir. Ölçekten en yüksek 85, en düşük 17 puan alınabilmektedir. Ölçekten alınan puan yükseldikçe yaratıcılık düzeyinin yüksek olduğu ifade edilmektedir (Şahin ve Danışman, 2017).

\section{Hoşgörü Ölçĕ̆i}

Demirci ve Ekşi (2018) tarafindan geliştirilen Hoşgörü Ölçeği, bireylerin hoşgörü düzeylerini belirlemeyi amaçlamaktadır. Ölçek 6 madde ve tek boyuttan oluşmaktadır. Ölçek beşli likert yapıdadır. Ölçek toplam puan üzerinden değerlendirilmiştir. Ölçek için yapılan analiz sonuçlarında, Hoşgörü Ölçeği’nin yapı geçerliğini değerlendirmek için yapılan açımlayıcı faktör analizi sonucunda toplam varyansın \% 41.854'ünü açıklayan özdeğeri 2.511 olan ve 6 maddeden oluşan tek boyutlu bir yapıya sahip olduğu bulunmuştur. Ölçekteki maddelerin faktör yükleri .57 ile .70 arasında sıralanmaktadır. Ölçeğin Cronbach alpha iç tutarlılık katsayısı .72 olarak hesaplanmıştır. Ölçeğin üç hafta arayla 32 katılımcıya yeniden uygulanmasından elde edilen test-tekrar test güvenirlik katsayısı .79 olarak bulunmuştur. Ölçekteki maddelerin düzeltilmiş madde toplam puan korelasyonları .38 ile .51 arasında değişmektedir. Ölçekten 30-6 arasında puan alınmaktadır. Ölçekten alınan yüksek puan hoşgörü düzeyinin yüksek olduğunu belirtmektedir (Demirci ve Ekşi, 2018).

\section{Verilerin Toplanmas1}

Araştırmada kullanılan Kişisel Bilgi Formu ve ölçekler çalışma grubundaki öğretmen adaylarına elden dağıtılmış, doldurmalarını takiben teslim alınmıştır. Uygulamadan önce çalışma grubuna araştırmanın önemi, eğitime getireceği katkı ve cevaplama samimiyetinin araştırma sonuçlarına 
yapacağ1 etkiden söz edilmiştir. Araştırmada eksik/hatalı doldurulan 5 anket formu ç1karılarak analizler 215 anket formu üzerinden tamamlanmıştır.

\section{Verilerin Analizi}

Araştırmada okul öncesi öğretmen adaylarının yaratıcılık ve hoşgörü düzeylerini betimlemek amacıyla ortalama ve standart sapma değerleri hesaplanmıştır. Dağılımın normal dağılım gösterip göstermediği belirlendikten sonra yaratıcılık ve hoşgörü düzeyleri arasındaki ilişkiyi tespit etmek amacıyla Pearson Momentler Çarpımı Korelasyon Katsayısı Analizi, öğretmen adaylarının ölçeklerden aldıkları puanların cinsiyet değişkenine göre farklılaşıp farklılaşmadığını belirlemek üzere Mann Whitney-U testi; sınıf düzeyi ve yaratıcılık dersi alıp almama değisskenlerine göre farklılaşıp farklılaşmadığını belirlemek üzere Bağımsız Grup T Testi Analizi uygulanmıştır. Veriler uygun istatistik paket programında çözümlenmiş ve anlamlılık düzeyi .05 olarak değerlendirilmiştir.

\section{BULGULAR}

Bu bölümde okul öncesi öğretmen adaylarının yaratıcılık ve hoşgörü düzeyleri arasındaki ilişkiyi belirlemeye yönelik bulguların yanı sıra; okul öncesi öğretmen adaylarının yaratıcılık ve hoşgörü düzeylerinin demografik özelliklerine göre (cinsiyet, sınıf düzeyi ve yaratıclık dersi alıp almama durumu) farklılaşıp farklılaşmadığına yönelik bulgulara yer verilmiştir.

Tablo 2. Öğretmen adaylarının yaratıcılık ve hoşgörü düzeylerine ilişkin ortalama ve standart sapma değerleri sonuçları

\begin{tabular}{lccc}
\hline & $\mathrm{N}$ & $\overline{\mathrm{X}}$ & ss \\
\hline Yaratıcı Kişilik Özellikleri Ölçeği & 215 & 65.33 & 11.17 \\
Hoşgörü Ölçeği & 215 & 23.97 & 3.93 \\
\hline
\end{tabular}

Tablo 2'de görüldüğü üzere okul öncesi öğretmen adaylarının Yaratıcı Kişilik Özellikleri Ölçeği’nden aldıkları puan ortalaması 65.33 (maksimum 85, minimum 17); standart sapma ise 11.17; Hoşgörü Ölçeği'nden aldıkları ortalama 23.97 (maksimum 30, minimum 6), standart sapma 3.93’tür. Ölçeklerden alınabilecek en yüksek ve en düşük puanlar değerlendirildiğinde öğretmen adaylarının yaratıcılık ve hoşgörü düzeylerinin yüksek olduğu tespit edilmiştir.

Tablo 3. Öğretmen adaylarının yaratıcllı düzeyleri ile hoşgörü düzeyleri arasındaki ilişkiye yönelik Pearson çarpım momentler korelasyon katsayısı sonuçları

$$
\text { Hoşgörü Ölçeği }
$$

\begin{tabular}{lll}
\hline Yaratıc1 Kişilik Özellikleri Ölçeği & $\mathrm{N}$ & 215 \\
\cline { 2 - 3 } & $\mathrm{r}$ & .77 \\
\cline { 2 - 3 } & $\mathrm{p}$ & $.000^{* * *}$ \\
\hline
\end{tabular}

$* * * p<.001$ 
Tablo 3’te görüldüğü üzere okul öncesi öğretmen adaylarının Yaratıcı Kişilik Özellikleri Ölçeği ile Hoşgörü Ölçeği’nden aldıkları puanlar arasında yüksek düzeyde, pozitif yönlü ve anlamlı bir ilişki olduğu tespit edilmiştir $(\mathrm{r}=0.77, \mathrm{p}<.001)$.

Tablo 4. Öğretmen adaylarının yaratıcllık ve hoşgörü puanlarının cinsiyet değişkenine göre farklılaşma durumuna ilişkin yapılan Mann Whitney-U Testi sonuçları

\begin{tabular}{llcccccc}
\hline & Cinsiyet & $\mathrm{N}$ & $\begin{array}{c}\text { Sıra } \\
\text { ortalaması }\end{array}$ & $\begin{array}{c}\text { Sıralar } \\
\text { toplamı }\end{array}$ & $\mathrm{U}$ & $\mathrm{z}$ & $\mathrm{P}$ \\
\hline Yaratıcı Kişilik & Kadın & 204 & 109.70 & 22378.50 & 775.500 & -1.726 & .084 \\
Özellikleri Ölçeği & Erkek & 11 & 76.50 & 841.50 & & & \\
\hline Hoşgörü Ölçeği & Kadın & 204 & 109.50 & 22338.50 & 815.500 & -1.532 & .126 \\
\hline
\end{tabular}

Tablo 4'te görüldüğü üzere, okul öncesi öğretmen adaylarının Yaratıcı Kişilik Özellikleri Ölçeği $(z=-1.726 ; p=.084)$ ve Hoşgörü Ölçeği'nden ( $z=-1.532 ; p=.126)$ aldıkları puanların cinsiyet değişkenine göre farklılaşıp farklılaşmadığını belirlemek üzere yapılan Mann Whitney-U Testi sonucunda grupların sıralama ortalamaları arasındaki farklılık anlamlı bulunmamıştır.

Tablo 5. Öğretmen adaylarının yaratıcılık ve hoşgörü puanlarının sınıf düzeyi değişkenine ilişskin Bağımsız Grup T Testi sonuçları

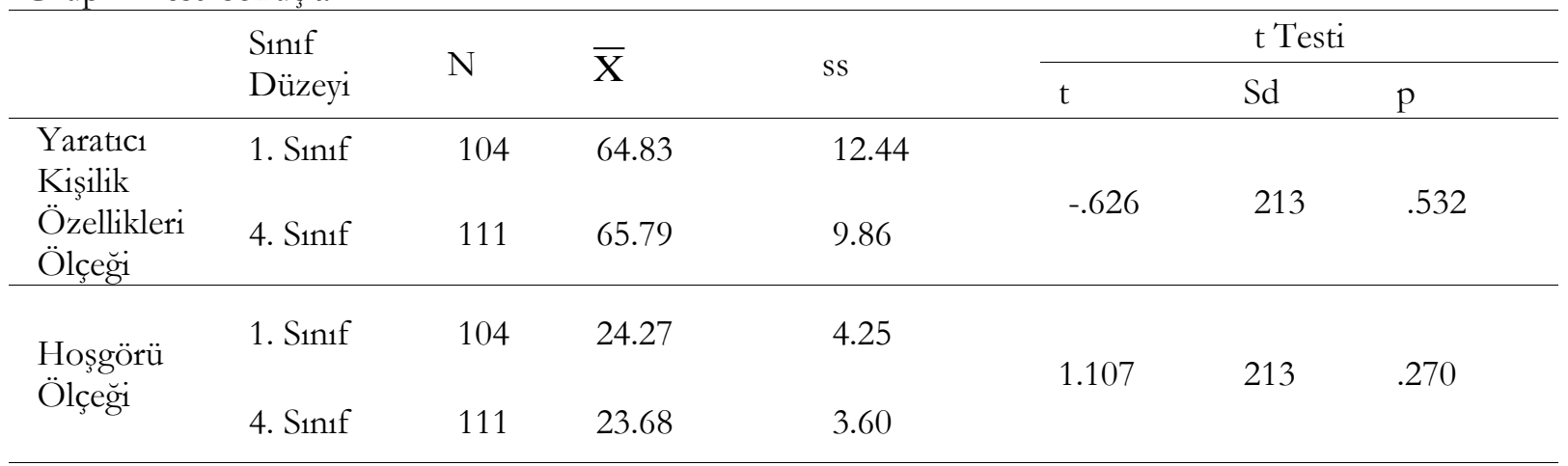

Tablo 5 incelendiğinde araştırmaya katılan okul öncesi öğretmen adaylarının Yaratıcı Kişilik Özellikleri Ölçeği ve Hoşgörü Ölçeği puanlarının sınıf düzeyi değişkenine göre anlamlı bir farklılık gösterip göstermediğini belirlemek amacıyla yapılan Bağımsız Grup T Testi sonucunda grupların aritmetik ortalamaları arasındaki farklılık anlamlı bulunmamıştır $(\mathrm{p}=.532 ; \mathrm{p}=.270)$.

Tablo 6. Öğretmen adaylarının yaratıcılık ve hoşgörü puanlarının yaratıcılık dersi alma değişkenine ilişkin Bağımsız Grup T Testi sonuçları

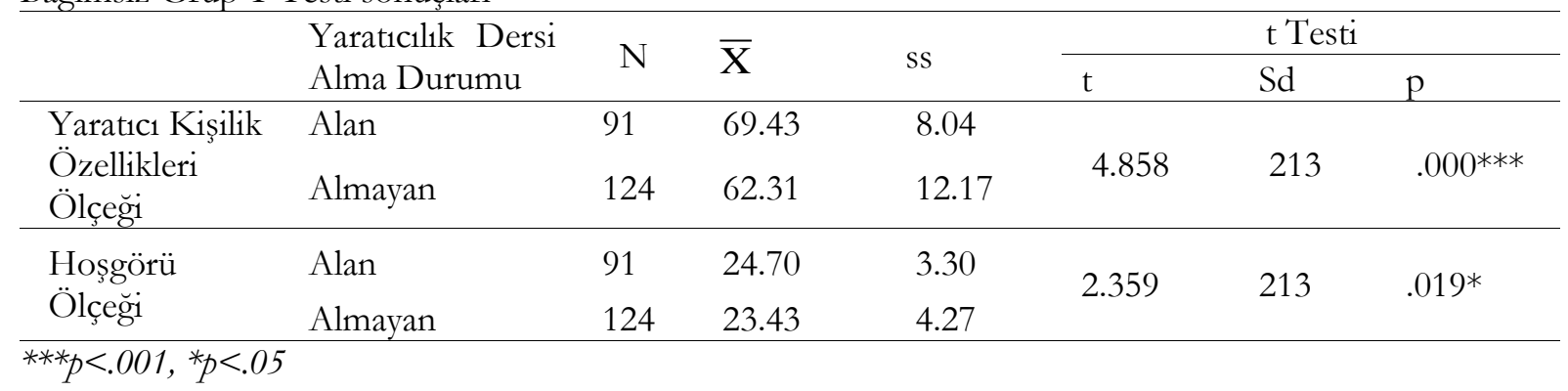


Tablo 6 incelendiğinde araştırmaya katılan okul öncesi öğretmen adaylarının Yaratıcı Kişilik Özellikleri Ölçeği ve Hoşgörü Ölçeği puanlarının yaratıcılık dersi alıp almama durumu değisskenine göre anlamlı bir farklılık gösterip göstermediğini belirlemek amacıyla yapılan Bağımsız Grup T Testi sonucunda grupların aritmetik ortalamaları arasındaki farklılık yaratıcllık dersi alan öğretmen adayları lehine anlamlı bulunmuştur $(\mathrm{p}<.001 ; \mathrm{p}<.05)$.

\section{SONUÇ ve TARTIŞMA}

Okul öncesi öğretmen adaylarının yaratıcılık ve hoşgörü düzeyleri arasındaki ilişkinin incelenmesi bu çalışmanın temel amacı olarak belirlenmiştir. Bu temel amaç doğrultusunda; öğretmen adaylarının yaratıcılık ve hoşgörü düzeyleri ile yaratıcılık ve hoşgörü düzeylerinin demografik özelliklere (cinsiyet, sınıf düzeyi ve yaratıcılık dersi alıp almama durumu) göre farklılaşma durumu da araştırılmıştır.

Araştırma sonucunda, çalışma grubunu oluşturan öğretmen adaylarının yaratıcılık ve hoşgörü düzeylerinin, ölçeklerden alınabilecek maksimum ve minimum puanlar değerlendirilerek, yüksek düzeyde olduğu görülmüştür. Alanyazına bakıldığında da öğretmen adaylarının en önemli gördüğü değerler arasında hoşgörünün yer aldığ1 tespit edilmiştir (Çekin, 2013; Çengelci, Gülay Ogelman ve Erten Sarıkaya, 2015; Hancı ve Karaduman, 2013; Kolaç ve Karadağ, 2012; Özdemir ve Sezgin, 2011; Uzun ve Köse, 2017). Mutluer’in (2015) çalışmasında hoşgörü kavramı öğretmen adayları için hayatın vazgeçilmezi olarak ifade edilmektedir. Yaratıcılık kavramına bakıldığında ise okul öncesi öğretmen adaylarının yaratıcılık düzeylerinin yüksek olduğu sonucuna ulaşılan pek çok çalışma vardır (Ekinci ve Kaya, 2016; Görgen ve Karaçelik, 2009; Toyran, 2015; Çetingöz, 2002; Temizkalp, 2010; Zeytun, 2010). Öte yandan Topoğlu (2015) ise, araştırmasının sonucunda okul öncesi öğretmen adaylarının yaratıcılık düzeylerinin ortalamanın altında olduğunu tespit etmiştir. $\mathrm{Bu}$ çalışmada öğretmenlerin hoşgörü ve yaratıcılık düzeylerinin yüksek çıkmasının çeşitli nedenleri olabilir. Öğretmen adaylarının kendilerini bu alanlarda geliştirecek kişisel gelişim programlarına katılmış olmaları neden olarak gösterilebilir.

Araştırmaya katılan okul öncesi öğretmen adaylarının yaratıcılık ve hoşgörü düzeylerinin cinsiyet değişkenine göre farklılaşmadığı görülmüştür. Bazı araştırmacılar da okul öncesi öğretmen adaylarının yaratıcılık düzeylerinin cinsiyete göre farklılaşmadığını tespit etmişlerdir (İşleyen ve Küçük, 2013; Temizkalp, 2010; Topoğlu, 2015; ve Zeytun, 2010). Öte yandan yaratıc1lıkta toplumsal kültür yapısından dolayı kadın öğretmen adaylarının yaratıcılık düzeylerinin erkek öğretmen adaylarından farklı olmasına yönelik bir beklenti olabilir (Çetingöz, 2002). Bu tür bulgular bu alanda yapılacak araştırma sayılarının arttırılmasıyla daha belirgin bir sonuca ulaşmayı sağlayabilir. Büyükkaragöz ve Kesici (1996) ilkokul öğretmenlerinin hossgörü konusunda 
sergiledikleri tutumlar arasında kadın öğretmenler lehine anlamlı fark olduğunu tespit etmiştir. Alanyazında kadınların toplumsal cinsiyet rolleri dolayısıyla erkeklerden daha hoşgörülü olarak alg1lanmalarına yönelik bulgular da mevcuttur (Babaoğlan, 2016; Yetim, 2002).

Araştırmanın sonucunda okul öncesi öğretmen adaylarının yaratıcılık ve hoşgörü düzeylerinin sınıf düzeylerine göre farklılaşmadığ1 ortaya konulmuştur. Topoğlu (2015) okul öncesi öğretmen adaylarının yaratıcılık düzeylerinin sınıf düzeyine göre farklılaşmadığını tespit etmiştir. Öte yandan Görgen ve Karaçelik (2009) araştırmalarının sonucunda 4. Sınıf okul öncesi öğretmen adaylarının yaratıcılık düzeylerinin 1. Sınıf öğretmen adaylarından daha yüksek olduğu sonucuna ulaşmışlardır. Çetingöz (2002) ve Zeytun (2010) ise 2. Sınıf okul öncesi öğretmen adaylarının yaratıcıllk düzeylerinin, 1. ve 3. Sınıf öğretmen adaylarından daha yüksek olduğu sonucuna ulaşmıştır. Bu sonucun ortaya çıkmasında öğretmen adaylarının sınıf düzeyinden ziyade kendilerini bu kişisel özellikler açısından geliştirmiş olup olmamaları etkili olmuş olabilir.

Araştırmaya katılan okul öncesi öğretmen adaylarının yaratıcılık ve hoşgörü düzeylerinin yaratıcılık dersi alıp almama durumlarına göre farklılaştığı tespit edilmiştir. Bu sonuca göre yaratıcılık dersi alan öğretmen adaylarının hoşgörü ve yaratıcılık düzeyleri, dersi almayan öğretmen adaylarından daha yüksektir. Bu da lisans öğrenimi sürecinde alınan derslerin (Erken Çocukluk Döneminde Yaratıcılık, İnsan İlişkileri ve İletişim) öğretmen adaylarında olumlu etkisinin olduğu şeklinde açıklanabilir.

Okul öncesi öğretmen adaylarının yaratıcılık düzeyleri ile hoşgörü düzeyleri arasında yüksek düzeyde, pozitif yönlü ve anlamlı bir ilişki olduğu görülmüştür. Bu sonuca göre okul öncesi öğretmen adaylarının hoşgörü düzeyleri arttıkça yaratıcılık düzeylerinin de arttığı söylenebilir. Pek çok araştırmacı da çalışmaları sonucunda bireylerin yaratıcılıklanı ile hoşgörü düzeyleri arasında pozitif bir ilişki olduğunu görmüşlerdir (Barron ve Harrington, 1981; Kornilova ve Kornilov 2010; Stoycheva, 2009; Stoycheva, 2008; Tegano, 1990; Zenasni, Besancon, ve Lubart, 2008). Buna karşılık Merrotsy (2013) bu konuda yapılan araştırmaları incelemiş ve böyle bir ilişkinin çok güçlü olmadığı, üzerinde daha çok çalışılması gerektiği konusunda (özellikle de eğitim alanında) görüş belirtmiştir. Nitekim alanyazın incelendiğinde de yaratıcllık ve hoşgörü ilişkisine bakan araştırmaların sınırlı sayıda olduğu görülmektedir (Balgiu, 2014; Zenasnı, Besançon ve Lubart, 2008).

Schreglmann ve Kazancı (2016), okul öncesi öğretmen adaylarının yaratıcı öğretmen kavramına yönelik metaforik algılarını inceledikleri araştırmada öğretmen adaylarının yaratıcı öğretmeni, hoşgörülü öğretmen kavramıyla tanımladıkları ortaya konulmuştur. Bu sonucun ortaya çıkmasında 
çocukların yaratıcılıklarının gelişimi için öğretmenlerin hoşgörülü ve yaratıcı kişilik özelliklerine sahip olmaları gerektiğinin bilincinde olmaları etkili olabilir (Erdoğdu, 2006).

Okul öncesi öğretmen adaylarının yaratıclık ve hoşgörü düzeyleri arasındaki ilişkinin incelendiği bu araştırmanın sonucunda araştırmacı ve uygulayıcılara bazı öneriler sunulabilir. Örneğin; öğretmen yetiştiren yükseköğretim kurumları, programlarını özellikle öğretmen adaylarını hoşgörü konusunda bilinçlendirmek ve geliştirmek için zenginleştirebilirler. Nitekim Kanada'da öğretmen eğitiminde bu konuya özel bir önem verildiği ifade edilmektedir (Mullen, 2018). Araştırmanın sonucunda yaratıcılık dersinin öğretmen adaylarının hoşgörü ve yaratıcılık düzeylerinde anlamlı farka yol açtı̆̆1 tespit edilmiştir. Buradan hareketle, lisans programlarında yaratıcılık dersinin içeriğinin zenginleştirilmesine, ders süresi ve/veya sayısının arttırılmasına yönelik çalışmalar yapılabilir. Toplumumuzda bilgiyi üreten, değerlendiren ve yeniden yapılandırabilen bireylere duyulan ihtiyaç her geçen gün artmaktadır. Bu nedenle, eğitim ortamlarında bilinmeyeni keşfetmeye yönelik uygun öğretim yöntemleri kullanılmalı ve doğuştan getirilen bir yetenek olan yaratıcılı̆̆ın geliştirilmesine yönelik uygulamalara yer verilmelidir (Vural, 2008). Ayrıca, öğretmen adaylarına onların merak duygusunu harekete geçirecek, araştırmaya ve soru sormaya yönelten davranışlar kazandıran yaratıcılık dersleri aracılığıyla yaratıcı düşünme ve beraberinde hoşgörü gelişecektir (Karakuş, 2000). Yaratıcılık eğitimi verilirken sergilenen tutum da bu süreçte öğretmen adaylarının hem hoşgörü hem de yaratıcılıklarını geliştirme adına önemlidir. YÖK tarafından yayınlanan güncel okul öncesi öğretmenliği lisans programına bakıldığında Alan Eğitimi Seçmeli Ders Listesinde yer alan 2 kredilik “Erken Çocuklukta Yaratıcılık ve Yaratıcı Çocuk Etkinlikleri” dersi göze çarpmaktadır. Bu ders dışında programda yaratıcılık ile ilgili herhangi bir ders bulunmamaktadır (YÖK, 2018). Yaratıcılık dersi programının bütününde ele alınarak öğretmen adaylarının lisans eğitimleri süresince yaratıcılık temelli bir alt yapıyla yetiştirilmeleri gerekmektedir. Mullen'e (2018) göre yaratıcılık ve eleştirel düşünme bugünün küresel yeterliliklerinden sayılmaktadır. Bu nedenle öğretmen yetiştiren programların bu konuya gereken önemi vermesi beklenmektedir. Öğretmen adaylarının yaratıcıllk ve hoşgörü konusunda kişisel gelişimlerine yönelik çalışmalar yapılabilir. Ayrıca bu araştırma nicel araştırma yöntemleri kullanılarak yürütülmüştür. Nitel araştırma yöntemleri kullanılarak, farklı örneklem grupları ile yeni araştırmalar yürütülebilir.

\section{KAYNAKÇA}

Akandere, M., Yarımkaya, E., \& Aslan, İ. (2014). Geleneksel çocuk oyunlarının ortaokul öğrencilerinin toplumsal cinsiyet eşitsizliğinde medyanın rolü, hoşgörü eğilim düzeyleri üzerine etkisi. Uluslararası Hakemli Psikiyatri ve Psikoloji Arastırmaları Dergisi, 2(2), 57-67. 
Altunay, E., \& Yalçınkaya, M. (2011). Öğretmen adaylarının bilgi toplumunda değerlere ilişkin görüsslerinin bazı değişkenler açısından incelenmesi. Kuram ve Uygulamada Eğitim Yönetimi Dergisi, 17(1), 5-28.

Aslan, Ö. (2001). Hoşgörü ve tolerans kavramlarına etimolojik açıdan analitik bir yaklaşım. Cumburiyet Üniversitesi İlahiyat Fakültesi Dergisi, 5(2), 357-380.

Aslan, S. (2017). İlkokul 4. sınıf öğrencilerinin hoşgörü eğilimleri ile yardımseverlik tutumlarının çeşitli değişkenler açısından incelenmesi. İnönü Üniversitesi Eğitim Fakültesi Dergisi, 18(1), 163 175.

Aydın, İ. (2016). Ögretimde denetim. Ankara: Pegem Akademi.

Aydın, M. Z. (2010). Okulda değerler eğitimi. Eğitime Bakış, 6(18), 6-19.

Babaoğlan, E. (2016). Kadın ve erkek eğitim denetmenlerinin kişisel ve mesleki özellikleri. Mersin Üniversitesi Eğitim Fakültesi Dergisi, 12(2), 757-769.

Balgiu, B. A. (2014). Ambiguity tolerance in productional creativity. Logos Universality Mentality Education Novelty, Section: Social Sciences, 3(1), 29-40.

Banks, J. A. (2008). An introduction to multicultural education. Boston: Pearson Education.

Barron, F., \& Harrington, D. M. (1981). Creativity, intelligence, and personality. Annual Review of Psychology, 32, 439-476.

Başarır, F., Sarı, M., \& Çetin, A. (2014). Examination of teachers' perceptions of multicultural education. Pegem Eğitim ve Ögrretim Dergisi, 4(2), 91-110.

Bayraktar, Ş., \& Çınar, D. (2010). Öğretmen adaylarının gözü ile fen ve teknoloji öğretmenlerinin etkili öğretmen davranışlarını gerçekleştirme düzeyleri. Abi Evran Üniversitesi Kırşehir Eğitim Fakültesi Dergisi, 11(3), 131-152.

Benedek, M., Nordtvedt, N., Jauk, E., Koschmieder, C., Pretsch, J., Krammer, G., \& Neubauer, A. C. (2016). Assessment of creativity evaluation skills: A psychometric investigation in prospective teachers. Thinking Skills and Creativity, 21, 75-84.

Boyac1, M., \& Ersever, O. G. (2017). Hoşgörü eğilimi geliştirme programının 5. sınıf öğrencilerinin hoşgörü ve zorbalık düzeylerine etkisi. Eğitim ve Bilim, 42(189), 167-182.

Büyükkaragöz, S., \& Kesici, Ş. (1996). Öğretmenlerin hoşgörü ve demokratik tutumları. Kuram ve Uygulamada Eğitim Yönetimi Dergisi, 2(3), 353-365.

Cihan, M. (1998). Felsefe ve hoşgörü üzerine. Atatürk Üniversitesi Türkiyat Araștormalar Enstitüsü Dergisi, 10, 169-173.

Csikszentmihalyi, M. (2015). The systems model of creativity: The collected works of Mihaly Csikszentmihalyi. Springer.

Çalışkan, M., Negiş Işık, A., \& Saygın, Y. (2013). Prospective teachers' perception of ideal teacher. İlkögretim Online, 12(2), 575-584.

Çekin, A. (2013). Öğretmen adaylarının ahlaki olgunluk düzeyleri. Kastamonu Eğitim Dergisi, 21(3), 1035-1048.

Çelik, T. (2011). Sosyal bilgiler ögretmen adaylarmm çok kültürlü bakıs açısı gelistirmelerinde medya okuryaz̧arlğ̆ dersinin rolüne ilişkin bir çalışma (Yayımlanmamış yüksek lisans tezi). Pamukkale Üniversitesi, Denizli.

Çengelci, T., Hanc1, B., \& Karaduman, H. (2013). Okul ortamında değerler eğitimi konusunda öğretmen ve öğrenci görüssleri. Değerler Eğitimi Dergisi, 11(25), 33-56. 
Çetingöz, D. (2002). Okulöncesi eğitimi ögretmenlï̆i ögrencilerinin yaratıc düsü̈nme becerilerinin gelişiminin incelenmesi (Yayımlanmamış yüksek lisans tezi). Dokuz Eylül Üniversitesi, İzmir.

Çınkır, Ş. (2004). Okulda etkili öğretmen-öğrenci ilişkisinin yönetimi. Milli Eğgitim Dergisi, 161, 1-12.

Çoban, A. E., Karaman, N. G., \& Doğan, T. (2010). Öğretmen adaylarının kültürel farklılıklara yönelik bakış açılarının çeşitli demografik değişkenlere göre incelenmesi. Abant İzæet Baysal Üniversitesi Ë̆itim Fakültesi Dergisi, 10(1), 125-131.

De Souza Fleith, D. (2000). Teacher and student perceptions of creativity in the classroom environment. Roeper Review, 22(3), 148-153.

Demirci, İ., \& Ekşi, H. (2018). Keep calm and be happy: A mixed method study from character strengths to well-being. Educational Sciences Theory and Practice, 18(29), 303-354.

Ekinci, N., \& Kaya, D. (2016). Okul öncesi eğitimi öğretmen adaylarının özel alan yeterlik algılarının incelenmesi: İletişim, yaratıcıllk ve estetik. Sakarya University Journal of Education, 6(1), 141157.

Erdoğdu, M. Y. (2006). Yaratıcılık ile öğretmen davranışları ve akademik başarı arasındaki ilişkiler. Elektronik Sosyal Bilimler Dergisi, 5(17), 95-106.

Görgen, İ., \& Karaçelik, S. (2013). Okul öncesi öğretmenliği ve fen bilgisi öğretmenliği öğrencilerinin yaratıcı düşünme beceri düzeylerinin karşılaştırmalı incelenmesi. Sosyal ve Beșeri Bilimler Araștırmalan Dergisi, 23, 129-146.

Hotaman, D. (2012). An investigation of pre-service teachers' perceptions of teacher personality characteristics. Journal of Theoretical Educational Science, 5(2), 186-201.

İşleyen, T., \& Küçük, B. (2013). Öğretmen adaylarının yaratıcı düşünme düzeylerinin farklı değişkenler açısından incelenmesi. Mustafa Kemal Üniversitesi Sosyal Bilimler Enstitüsü Dergisi, 10(21), 199-208.

Kalın, Z. T., \& Nalçacı, A. (2017). Ortaokul 5. sınıf öğrencilerinin hoşgörü eğilimlerinin çeşitli değişkenler açısından incelenmesi. Bayburt Ë̆itim Fakültesi Dergisi, 12(23), 293-304.

Karakuş, M. (2000). Alt sosyo-ekonomik düzeydeki ilköğretim ikinci smnf ögrencilerinin yaratıcllk düzeylerine yaratıc sorun çözme programının etkisi (Yayımlanmamış yüksek lisans tezi). Çukurova Üniversitesi, Eğitim Bilimleri Enstitüsü, Adana.

Karasar, N. (2005). Bilimsel arastırma yöntemi. Ankara: Nobel Yayın Dağıtım.

Kaya, H. İ. (2010). Öğretmen eğitiminde yapılandırmacı ögrenmeye dayah uygulamalarn öğretmen adaylarmm problem çözme, elesstirel düşüme ve yaratıc düş̈̈nme eğilimlerine etkileri (Yayımlanmamış doktora tezi). Atatürk Üniversitesi, Erzurum.

Kesicioğlu, O. S., \& Deniz, Ü. (2014). Okul öncesi öğretmen adaylarının öğretmenlik mesleğine ilişkin tutumları ile eleştirel düşünme ve yaratıcılık becerileri arasındaki ilişkinin incelenmesi. Turkish Studies-International Periodical For The Languages, Literature and History of Turkish or Turkic, 9(8), 651-659.

Kılıç, A. (2006). Öğretmen adaylarının öğretmenlik becerilerini uygulama ve gözleme düzeyleri. Sosyal Bilimler Dergisi, 16, 155-168.

Kılıç, M., Kaya, A., Yıldırım, N., \& Genç, G. (2004). Eğitimci göə̈̈ulle ögretmen ve ögrrenci. XIII. Ulusal Egitim Bilimleri Kurultayı, Malatya.

Kıroğlu, K., Elma, C., Kesten, A., \& Egüz, Ş. (2012). Üniversitede demokratik bir değer olarak hoşgörü. Journal of Social Studies Education Research, 3(2), 86-104. 
Korkmaz, S. (2000). Türklerde hoşgörü. Erciyes Üniversitesi Sosyal Bilimler Enstitüsü Dergisi, 1(9), 491502.

Kornilova, T. V., \& Kornilov, S. A. (2010). Intelligence and tolerance/intolerance for uncertainty as predictors of creativity. Psychology in Russia: State of The Art, 3, 240-256.

Merrotsy, P. (2013). Tolerance of ambiguity: A trait of the creative personality? Creainvity Research Journal, 25(2), 232-237.

Moran, S. (2010). Changing the world: Tolerance and creativity aspirations among American youth. High Ability Studies, 21(2), 117-132.

Mullen, C. A. (2018). Global leadership: competitiveness, tolerance and creativity-a Canadian provincial example. International Journal of Leadership in Education, 1-15.

Mumford, M. D. (2003). Where have we been, where are we going? Taking stock in creativity research. Creativity Research Journal, 15(2-3), 107-120.

Mumford, M. D., Medeiros, K. E., \& Partlow, P. J. (2012). Creative thinking: Processes, strategies and knowledge. Journal of Creative Behavior, 46, 30-47.

Mutluer, C. (2015). Sosyal bilgiler öğretmen adaylarının "hoşgörü" kavramına ilişkin metaforik alg1lar1. Tarih Okulu Dergisi, 8(22), 575-595.

Ogelman, H., G. \& Erten Sarıkaya, H. (2015). Okul öncesi eğitimi öğretmenlerinin değerler eğitimi konusundaki görüşleri: Denizli ili örneği. Sakarya Üniversitesi Eğitim Fakültesi Dergisi, 29, 81100.

Oğuz, E. (2012). Öğretmen adaylarının değerler ve değerler eğitimine ilişkin görüşleri. Kuram ve Uygulamada Ë̆itim Bilimleri, 12(2), 1309-1325.

Oğuzkan, Ş., Demiral, Ö., \& Tür, G. (2001). Okul öncesinde yaratıc çocuk etkinlikleri. İstanbul: Ya$\mathrm{Pa}$.

Özdemir, S., \& Sezgin, F. (2011). Öğretmen adaylarının bireysel ve örgütsel değerler ile öğrencilerde görmek istedikleri değerlere ilişkin önem sırası algıları. Ușak Üniversitesi Sosyal Bilimler Dergisi, $4(2), 1-21$.

Özerbaş, M. A. (2011). Yaratıcı düşünme öğrenme ortamının akademik başarı ve bilgilerin kalıcıllğga etkisi. Gari Üniversitesi Gar̨i Eğitim Fakültesi Dergisi, 31(3), 675-703.

Polat, S. (2009). Öğretmen adaylarının çok kültürlü eğitime yönelik kişilik özellikleri. International Online Journal of Educational Sciences, 1(1), 154-164.

Rıza, E. T. (2004). Yaratıcliğ geliştirme teknikleri. İzmir: Birleşik Matbaa.

Robinson, K. (2001). Yaratıclık, aklın sımılarm aşmak (N. Geyran Koldaş, çev.). İstanbul: Kitap Yayınevi.

Runco, M. A. (2007). Creativity theories and themes: Research, development, and practice. Burlington, MA: Elsevier Academic Press.

Sadık, F. (2002). Sınıf içindeki problem davranışların nedenleri. Eğitim Araștırmaları Dergisi, 9, 106115.

Sapsağlam, Ö. (2016). Okul öncesi eğitim programlarında yer alan hedeflerin değerler açısından incelenmesi. Electronic Turkish Studies, 11(9), 683-700.

Schreglmann, S., \& Kazanc1, Z. (2016). Öğretmen adaylarının “yaratıcı öğretmen” kavramına yönelik metaforik algıları. Üstün Zekâhlar Eğitimi ve Yaratıcllk Dergisi, 3(3), 21-34. 
Sternberg, R. J., \& Grigorenko, E. L. (2004). Successful intelligence in the classroom. Theory into Practice, 43, 274-280.

Stone, J. G. (2000). The classroom as community: Ideas from an early childhood teacher. 23.04 .2019 tarihinde https:// files.eric.ed.gov/fulltext/ED443584.pdf adresinden erişildi.

Stoycheva, K. (2008). The new and the best: Ambiguity tolerance and creativity motivation. XXIX International Congress of Psychology, 20-25.

Stoycheva, K. (2009). Tolerance for ambiguity, creativity and personality. 23.04 .2019 tarihinde http://eprints.nbu.bg/1705/1/SEERCP2009 Katya\%20Stoycheva.pdf adresinden erișildi.

Sünbül, A. M. (2006). Bir meslek olarak öğretmenlik. Ö. Demirel ve Z. Kaya (Ed.), Ögrretmenlik mesleğine giriş içinde (ss. 306-331). Ankara: Pegem Akademi.

Şahin, F., \& Danışman, Ş. (2017). Yaratıcı Kişilik Özellikleri Ölçeği: Güvenilirlik ve geçerlik çalışması. Karabük Üniversitesi Sosyal Bilimler Enstitüsü Dergisi, 7(2), 747-760.

Tegano, D. W. (1990). Relationship of tolerance of ambiguity and playfulness to creativity. Psychological Reports, 66(3), 1047-1056.

Tegano, D. W., Groves, M. M., \& Catron, C. E. (1999) Early childhood teachers' playfulness and ambiguity tolerance: Essential elements of encouraging creative potential of children. Journal of Early Childhood Teacher Education, 20(3), 291-300.

Temizkalp, G. (2010). Öğretmen adaylarmnn yaratıcllk düzeyleri (Yayımlanmamış yüksek lisans tezi). Mehmet Akif Ersoy Üniversitesi, Sosyal Bilimler Enstitüsü, Burdur.

Topoğlu, O. (2015). Eğitim fakültesinde öğrenim gören öğretmen adaylarının yaratıcılık düzeylerinin çeşitli değişkenler açısından incelenmesi: ADÜ (Adnan Menderes Üniversitesi örneği). The Journal of Academic Social Science Studies, 35, 371-383.

Torrance, E. P. (1972). Predictive validity of the Torrance tests of creative thinking. The Journal of Creative Behavior, 6(4), 236-262.

Torrance, E. P. (1981). Predicting the creativity of elementary school children (1958-1980) and the teacher who "made a difference." Gifted Child Quarterly, 23(2), 55-62.

Toyran, G. (2015). Okul öncesi ögretmen adaylarnmn yaratıc düșünme düzeylerinin ve eleștirel düș̈̈nme eğilimlerinin bą̧ değğskenler açısından incelenmesi (Yayımlanmamış yüksek lisans tezi). Dokuz Eylül Üniversitesi, İzmir.

Tuncel, G., \& Balc1, A. (2015). Demokratik toplumlarda öğretmen nitelikleri ve öğrencilere yansımaları. Marmara Coğrafya Dergisi, 31, 82-97.

Türe, H., \& Ersoy, A. F. (2015). Sosyal bilgiler öğretmenlerinin hoşgörü eğitimine bakışı ve hoşgörü eğitimine ilişkin uygulamaları. Anadolu Journal of Educational Sciences International, 5(1), 57-87.

Uzun, M., \& Köse, A. (2017). Okul öncesi eğitimde değerler eğitiminin uygulanmasına yönelik öğretmen görüşleri. Bayburt Eğitim Fakültesi Dergisi, 12(23), 305-338.

Üste, R. B. (2007). İnsan hakları eğitimi ve ilköğretimdeki önemi. Ege Academic Review, 1, 295-310.

Üstündağ, T. (1998). Yaratıcı drama eğitim programının öğeleri. Eğitim ve Bilim, 22(107), 28-35.

Üstündăg, T. (2005). Yaratıcllğa yolculuk. Ankara: Pegem Akademi.

Vural, C. T. (2008). Sosyal bilgiler eğitiminde yaratıc düş̈̈nme: Yeni ilkëğretim programı beșinci sinnf sosyal bilgiler ögretiminde kullamlan etkinliklerin yaratıcılĭg gelistirmesi açısindan değerlendirilmesi 
(Yayımlanmamıs Yüksek Lisans Tezi). Çukurova Üniversitesi, Eğitim Bilimleri Enstitüsü, Adana.

Vygotsky, L. S. (2004). Imagination and creativity in childhood. Journal of Russian and East European Psychology, 29, 73-88.

Yazıcı, F. (2017). Osmanlı'dan Cumhuriyet'e hoşgörü: 7. sınıf öğrencilerinin farkındalıkları üzerine bir değerlendirme. Erzincan Üniversitesi Ë̆itim Fakültesi Dergisi, 19(2), 37-56.

Yeşilkayalı, E., \& Demirtaş, V. Y. (2013). Ebeveynlerin çocuk haklarına ilisskin tutumları ile ilköğretim öğrencilerinin hoşgörü eğilimleri arasındaki ilişki. Doku乏. Eylül Üniversitesi Buca Eg̈itim Fakültesi Dergisi, 36, 12-25.

Yetim, A. A., \& Göktaş, Z. (2004). Öğretmenin mesleki ve kişisel nitelikleri. Kastamonu Ĕ̈̆tim Dergisi, 12(2), 541-550.

Yetim, N. (2002). Sosyal sermaye olarak kadın girişimciler: Mersin örneği. Ege Akademik Bakış Dergisi, 2(2), 79-92.

Yıldırım, A., Ünal, A., \& Çelik, M. (2011). Öğretmen kavramına ilişkin öğretmen, yönetici ve müfettiş algılarının analizi. Uluslararası İnsan Bilimleri Dergisi, 8(2), 92-109.

Yıldı, Y. (2018). Mü̊ik ögretmen adaylarmm yaratıc düşüme becerilerinin incelenmesi (Cumburiyet Üniversitesi Örneği) (Yayımlanmamış yüksek lisans tezi). Cumhuriyet Üniversitesi, Eğitim Bilimleri Enstitüsü, Sivas.

YÖK (2018). Yeni öğretmen yetiştirme lisans programları. 24.04.2019 tarihinde https://www.yok.gov.tr/kurumsal/idari-birimler/egitim-ogretim-dairesi/yeni-ogretmenyetistirme-lisans-programlari adresinden erişildi.

Zakin, A. (2012). Hand to hand: teaching tolerance and social justice one child at a time. Childhood Education, 88(1), 3-13.

Zenasnı, F., Besançon, M., \& Lubart, T. (2008). Creativity and tolerance of ambiguity: An empirical study. The Journal of Creative Behavior, 42(1), 61-73.

Zeytun, S. (2010). Okul öncesi ögretmenliği ögrencilerinin yaratıcllk ve problem çözme düzeyleri arasindaki ilişkinin incelenmesi (Yayımlanmamış yüksek lisans tezi). Dokuz Eylül Üniversitesi, Eğitim Bilimleri Enstitüsü, İzmir. 